\title{
Varieties of export-oriented entrepreneurship in Asia
}

\author{
Siri Terjesen • Jolanda Hessels
}

Published online: 31 March 2009

C The Author(s) 2009. This article is published with open access at Springerlink.com

\begin{abstract}
This paper explores differences in the proportion of export-oriented earlystage entrepreneurial activity in 12 Asian countries. Drawing on varieties of capitalism theory, we find that Asian countries with high quality institutions are more likely to have higher proportions of young export-oriented firms. However, analysis on a 51 country data set indicates that Asian countries have significantly fewer young export-oriented firms than do non-Asian countries. Furthermore, the multi-country study reveals that countries with higher proportions of export-oriented entrepreneurial activity tend to have flexible industrial relations, high quality vocational training, and confrontational labor-employer relations, however the proportion of export-oriented new ventures is not related to the quality of corporate governance and inter-firm relations.
\end{abstract}

Siri Terjesen and Jolanda Hessels contributed equally.

We appreciate developmental feedback from the three special issue editors, two anonymous reviewers, and participants at the APJM Varieties of Capitalism conference and the Queensland University of Technology Entrepreneurship bootcamp. This research was financed by a Faculty Research Initiative Grant from Queensland University of Technology and EIM's SCALES research program.

S. Terjesen $(\bowtie)$

Kelley School of Business, Indiana University, 1309 E. 10th St., Bloomington, IN 47405, USA

e-mail: terjesen@indiana.edu

S. Terjesen

Entrepreneurship, Growth \& Public Policy Group, Max Planck Institute of Economics,

Kahlaische Straße 10, 07745 Jena, Germany

J. Hessels

EIM Business and Policy Research, Bredewater 26, P.O. Box 7001, 2701 AA Zoetermeer,

The Netherlands

e-mail: jolandahessels@yahoo.com

J. Hessels

Erasmus School of Economics, Erasmus University, Burgemeester Oudlaan 50, P.O. Box 1738, 3000 DR Rotterdam, The Netherlands 
Keywords International entrepreneurship - Varieties of capitalism - International business $\cdot$ Economic growth $\cdot$ Development $\cdot$ Institutional structures ·

Export orientation

Entrepreneurship, the "creation of new organizations" (Gartner, 1988: 26), is a major engine of economic growth in developed and developing economies (Acs \& Audretsch, 2000; Schumpeter, 1934), including in Asia (Dana, 2007; Hawkins, 1993). Entrepreneurs introduce innovations which are valued in their home countries and abroad. Around the world, local, regional and national governments have taken steps to stimulate the establishment of new firms and the growth of existing firms (Storey \& Tether, 1998; OECD, 2003). In particular, governments are interested in facilitating the development of locally-based firms that will export overseas. Exports aid the growth of both firms (Lu \& Beamish, 2001) and their home countries' economies by improving a nation's foreign exchange reserves, developing national industry and creating employment (Girma, Greenaway, \& Kneller, 2004). Traditionally, most exporting was undertaken by large multinational enterprises; however an increasing number of earlystage firms achieve foreign market sales (Rugman \& Wright, 1999). Asia is often noted for its strong potential (The Economist, 2002; Knowledge@Wharton, 2007), but disappointing progress (Carney \& Gedajlovic, 2000; The Economist, 2002).

The emerging academic literature focuses on firm- or founder-level explanations for international new venture activity and has mostly overlooked the role of institutions (Yeung, 2002). The composition and quality of institutions impact entrepreneurial activity (Reynolds, Bygrave, \& Autio, 2004), including the growth expectations of new ventures (Autio \& Acs, 2008; Bowen \& De Clercq, 2008) and the availability of informal venture capital (Szerb, Terjesen, \& Rappai, 2007). ${ }^{1}$

The present exploratory study is guided by the following research question: How are institutional structures related to the proportion of export-oriented, early-stage entrepreneurial activity in 12 Asian countries? In particular, we are interested in the role of five institutional spheres identified by Hall and Soskice (2001): industrial relations, vocational training and education, corporate governance, inter-firm relations and employee relations. Our research makes several contributions. First, we answer calls for comparative, theory-based research in international entrepreneurship (Baker, Gedajlovic, \& Lubatkin, 2005) and the integration of political economy perspectives (Carney, 2004; Whitley, 1999) by developing a varieties of capitalism approach to investigate the relationship between national-level institutions and export-oriented entrepreneurial activity. The varieties of capitalism (VoC) perspective assumes that national governments shape institutions which in turn structure economic activity, set behavioral norms, expectations and strategies (Hall \& Soskice, 2001: 9), including internationalization (Whitley, 1998). Also, as extant VoC research focuses on established firms operating in developed economies in North America and Europe (e.g., Whitley, 1999; Hall \& Soskice, 2001), our study answers calls for the extension of $\mathrm{VoC}$ to developed and developing countries in Asia (Haggard, 2004). Furthermore, we make a comparative study of institutional structures in 51 countries, including 12 Asian countries and offer implications for theory, practice and policy.

\footnotetext{
${ }^{1}$ For example, Autio and Acs (2008) find that country level variables, such as IPR protection, moderate the extent to which individuals will exploit human capital and financial capital in new ventures.
} 
There are several motivations for using Asia as a field for examining the relationship between institutions and international entrepreneurship. First, Asian countries are characterized by great heterogeneity across institutional structures (Hamilton \& Biggart, 1988) which play a major role in shaping the region's business systems and economic growth (e.g., Carney, 2004; Haggard, 2004). Asian institutional structures are closely intertwined and mutually reinforcing (Kuruvilla, 1998), but changing rapidly (Clarke, Lee, \& Li, 2004). For example, following independence, former colonies such as India and Malaysia established trade unions and arbitrating bodies to eliminate wage competition, promote labor cooperation and promote economic development (Frenkel \& Kuruvilla, 2002). Furthermore, the role of institutions in enabling the growth of new firms in Asia is increasingly acknowledged. For example, some South Asian economies established NASDAQinspired stock exchange markets to support new and small growth-oriented ventures (Carney \& Gedajlovic, 2000). The Asian region's ability to generate fast-growing, globally-oriented, often technology-intensive firms is critical to its performance on the world stage and continued economic development. Furthermore, many Asian countries are "emerging" economies which offer a natural experiment for research (Peng, 2003) and where export-oriented entrepreneurship significantly contributes to economic growth (Hessels \& van Stel, 2007).

\section{Theoretical background}

Varieties of capitalism theory

Varieties of capitalism (VoC) theory examines the role of institutions in shaping firm behavior. We follow Hall and Soskice (2001: 9) and North (1990: 3) in defining institutions as "a set of rules, formal or informal, that actors generally follow, whether for normative, cognitive, or material reasons" and organizations as "durable entities with formally recognized members, whose rules also contribute to the institutions of the political economy." Bridging business policy and strategy and political economy approaches, the VoC approach assumes that the nation-state shapes the most critical institutions and national-level differences in these institutions affect the structure of firms. ${ }^{2}$ Institutions enable the exchange of information, monitoring of behavior and sanction non-cooperative behavior and as such, set norms or attitudes about proper behavior (e.g., "rules of the game") and provide actors with resources and strategic capacities that they otherwise would not have attained. Institutions can be mutually reinforcing and there are sets of institutional complementarities.

A key assumption of the $\mathrm{VoC}$ approach is that national economies organize themselves differently, but can result in similar levels of economic performance or firm behavior. Thus, within the VoC approach, one system is not necessarily regarded as better than another. Each economy develops specific capacities for

\footnotetext{
${ }^{2}$ Other scholars have advanced VoC perspectives including Whitley (1999) and Streeck and Yamamura (2001), however we focus on the framework laid out in Hall and Soskice (2001). Bowen and De Clercq (2008) test Whitley's national business systems theory on high growth entrepreneurship.
} 
coordination which condition the actions that its firms and governments will undertake. ${ }^{3}$

Furthermore, the structure of the business environment does not result directly from the formal institutions. Rather, VoC views the political economy as populated by a variety of actors who seek to advance their interests in interactions with others (Hall \& Soskice, 2001). Firms are at the center of the analysis of corporate capitalism and $\mathrm{VoC}$ examines firms' relationships with internal and external stakeholders. There are multiple sets of equilibria that could exist and the structure depends on the iterative actions of actors in the environment. Extant VoC theory describes the impact of institutions on "the firm" which is generally considered to be large and well-established. Furthermore, the only economies classified in most accounts of $\mathrm{VoC}$ are OECD nations with time-honored multinational firms. National economies around the world are, however, populated by a mixture of firms of all sizes and ages which interact. For example, new ventures will often use established multinational firms' supply chains to diffuse their innovations (Acs \& Terjesen, 2007). In this paper, we extend VoC theory to explore how national institutions might structure export-oriented entrepreneurial activity among early stage firms. This approach requires revisiting some of the central assumptions of VoC theory which were directed to large, established firms and examining these in the context of new (and often small) ventures.

\section{Institutional influences on export-oriented entrepreneurial activity}

Institutional theory is concerned with the process by which structures become established as authoritative guidelines for social behavior and, at the macro level, how these environments affect organizational forms and processes. Institutional theory has been interpreted and applied in a range of fields, from sociology (here a tendency to focus on normative elements) to economics (regulative elements) (Scott, 2005). As articulated above, the present study is based on Hall and Soskice's (2001) VoC approach to institutional theory.

A growing body of entrepreneurship literature explores the role of formal and informal institutions in facilitating entrepreneurship, often focusing on how institutions enable varying degrees of capital accumulation which promote investment and growth in entrepreneurial activities. In one of the seminal works, Baumol (1990) highlights how the presence of innovation and corruption result in

\footnotetext{
${ }^{3} \mathrm{VoC}$ perspectives frequently examine political economies in terms of their spectrum from liberal market economies (LMEs) to coordinated market economies (CMEs). Firms in LMEs tend to coordinate their activities in hierarchies or through competitive market arrangements. Asian LMEs include Australia and New Zealand. In contrast, firms operating in CMEs rely upon non-market relations that generally include relational or incomplete contracting. CMEs include Japan and Korea. The distinction between CME and LME modes confers particular institutional advantages, for example leading to radical innovations in LMEs and incremental innovations in CMEs (Hall \& Soskice, 2001). The LME-CME strand of analysis is criticized for its binary assessment of the nature of capitalism (Whitley, 1999) and for its inability to predict technological innovation (Taylor, 2004) which is associated with export-oriented entrepreneurial activity (Autio, 2007). Furthermore, the VoC approach has been criticized for not having enough variety (Allen, 2004) and not considering changes in institutions (Hall \& Thelen, 2005). Many developing Asian economies have yet to adapt one system or the other and may develop unique hybrid approaches (Ritchie, 2009). Our study does not consider the classification of countries by LME or CME, although we do speak to the extent of coordination in markets.
} 
different levels of productive, unproductive and destructive entrepreneurship. Subsequent scholars have shown that entrepreneurial activity rates are impacted by national government differences in taxation, registration and incorporation rates, financial and educational capital (Autio \& Acs, 2008; Bowen \& De Clercq, 2008), and informal or "soft" institutions such as culture (Davidsson, 1995; Elam \& Terjesen, 2007). In the introduction of The architecture of markets, Fligstein (2002: 3-4) summarizes the role of internal organization and external environment relationships in facilitating entrepreneurial entry,

"Opportunistic entrepreneurs find a new market for some good or service. This new market often results from a technological breakthrough. Then, others see the opportunity to enter the same market. This creates competition that forces producers to make products more efficiently and at lower cost... the story is partial at best... Moreover, firms operate against an extensive backdrop of common understandings, rules and laws. These are most often supplied by governments. One cannot overestimate the importance of governments to modern markets. Without stable, more or less non-rent-seeking states, modern production markets would not exist... Competition and technological change are themselves defined by market actors and governments over time. These forces are not exogenous to market society, but endogenous to these social relations."

Taken together, extant research indicates institutions impact entrepreneurship but this impact varies with the many measures of institutions and of entrepreneurial activity. For example, McMullen, Bagby, and Palich (2008) report that opportunitymotivated entrepreneurial activity is associated with property rights and necessitymotivated entrepreneurial activity is related to fiscal and monetary freedoms. The lack of consistent definitions and measures of institutions and entrepreneurship, coupled with a lack of theory and a multitude of countries under study, suggest the need for a more careful and theoretical approach to examining linkages.

Building on $\mathrm{VoC}$, we argue that there are multiple ways in which institutions impact entrepreneurial firms' export orientation. In general, the differing structures of national institutions are reflected in two components: (1) the quantity and quality of export-oriented entrepreneurial opportunities present in the environment and, if such opportunities exist, (2) the ability of local entrepreneurs to take advantage of these. ${ }^{4}$

New firms are particularly susceptible to institutional environments and adopt practices which reflect their environments (Carney \& Gedajlovic, 2003). In order to export their new goods and services, new ventures rely on a resource advantage such as the possession of specific know-how, a proprietary technology or specific management capabilities (Autio, Sapienza, \& Almeida, 2000). While many of these resources may be embedded in the entrepreneur or firm, new ventures rely strongly on input from other economic actors in order to acquire and retain such a specific advantage. Compared to established firms, new ventures are more likely to have knowledge provided by external actors as an important element in the knowledge

\footnotetext{
${ }^{4}$ Institutional theory is relevant in explaining entrepreneurs' decisions of whether or not to export (Hessels \& Terjesen, 2009).
} 
production function (Acs \& Audretsch, 2000). Based on the approach outlined above, we believe that national institutions play an important facilitating role in providing new ventures with certain capacities that increase their likelihood of exporting. Furthermore, for new ventures, export activity entails high levels of risk due to liabilities of smallness, newness and foreignness. Thus entrepreneurs must be willing and prepared to take such risks, and certain sets of institutions may diminish or increase these risks.

\section{Asian context}

In studies of management and firm behavior, it is important to consider context (Johns, 2006), including national environments such as those found in Asia (Meyer, 2006; Yang \& Terjesen, 2007). Asia is a heterogeneous region, with countries varying widely in their levels of entrepreneurial activity, economic development and export orientation. For example, as measured by gross domestic product (GDP) per capita, Japan, Singapore, and Australia are quite wealthy while India, Indonesia, and the Philippines are comparatively poor. (See Dana, 2007, for an historical overview of the sociocultural and political economic context of entrepreneurship in Asia.)

There are, however, several common denominators among Asian countries. First, since the 1960s, Asian countries have experienced rapid, mostly governmentled industrialization. Second, from mid-1997, Asian countries encountered varying degrees of an economic crisis, including the contracting of export markets and the devaluation of currency (Carney \& Gedajlovic, 2000). The crisis prompted calls for Asian governments to increase investments in human capital and technology and to build structures which support the pursuit of high-growth entrepreneurial opportunities; however much of the region is still characterized by under-developed institutions (Carney \& Gedajlovic, 2000). Furthermore, the Asian region has deeply-embedded strategic and structural persistence, employing the same strategies in the same industries since initial industrialization. Asian countries are also characterized by low levels of cooperation and trust among government bureaucrats and entrepreneurs and high numbers of small firms (Dana, 2007) and familial capitalism (Steier, 2009). Established Asian firms, particularly family business groups, are burdened by extensive administrative heritage and are not always able to seize new opportunities in the post-Cold War and post-colonial eras (Carney \& Gedajlovic, 2003; Ahlstrom, Young, Chan, \& Bruton, 2004). In contrast, new firms may be able to take advantage of these opportunities, including the possibility to sell to customers offshore. An increasing number of Asians acquire university education and business experience overseas before returning home to establish export-oriented businesses (Ahlstrom, Young, Chan, \& Bruton, 2004). For example, Asian employees gain experience domestically, in the local offices of foreign MNEs and then leave to establish their own firms which engage in business overseas (Terjesen, O'Gorman, \& Acs, 2008). Export-oriented entrepreneurial efforts are often highly innovation-intensive and tend to have higher growth expectations (Autio, 2007) which can further develop a nation's economic environment, a relationship explored in the next section. 
Entrepreneurial activity and economic development

A major stream of entrepreneurship research concerns the relationship between entrepreneurial activity levels and economic development. Several scholars suggest that the relationship between entrepreneurship and economic development is Ushaped (e.g., Wennekers \& Thurik, 1999). That is, entrepreneurial activity levels tend to be higher in countries with very high and very low levels of GDP per capita. Take, for example, the Philippines or Indonesia, where rates of early-stage entrepreneurship (mostly driven by necessity-based entrepreneurship) are among the highest in the world yet the GDP per capita is less than $\$ 5,000$. In contrast, Australia has one of the highest levels of both GDP per capita $(\$ 32,000)$ and entrepreneurial activity (11.9\%), which is largely opportunity-based. In modeling this curve, Wennekers and Thurik (1999) assume that a modest number of innovative entrepreneurs can be found among the self-employed and that this number depends upon historical, institutional and structural factors. Relatedly, a core assumption of the Comparative Discovery, Evaluation and Exploitation (CDEE) international entrepreneurship framework (Baker et al., 2005) is that a country's institutional context influences the type of opportunities available and the individuals who will discover, evaluate and exploit them. Figure 1 depicts the relationship between entrepreneurial activity and economic development in 42 countries, including 12 Asian countries.

As shown in Figure 1, low income countries such as the Philippines, Indonesia, China and Thailand have some of the highest rates of entrepreneurial activity in the world. Economists interpret the U-shaped curve to suggest that extensive

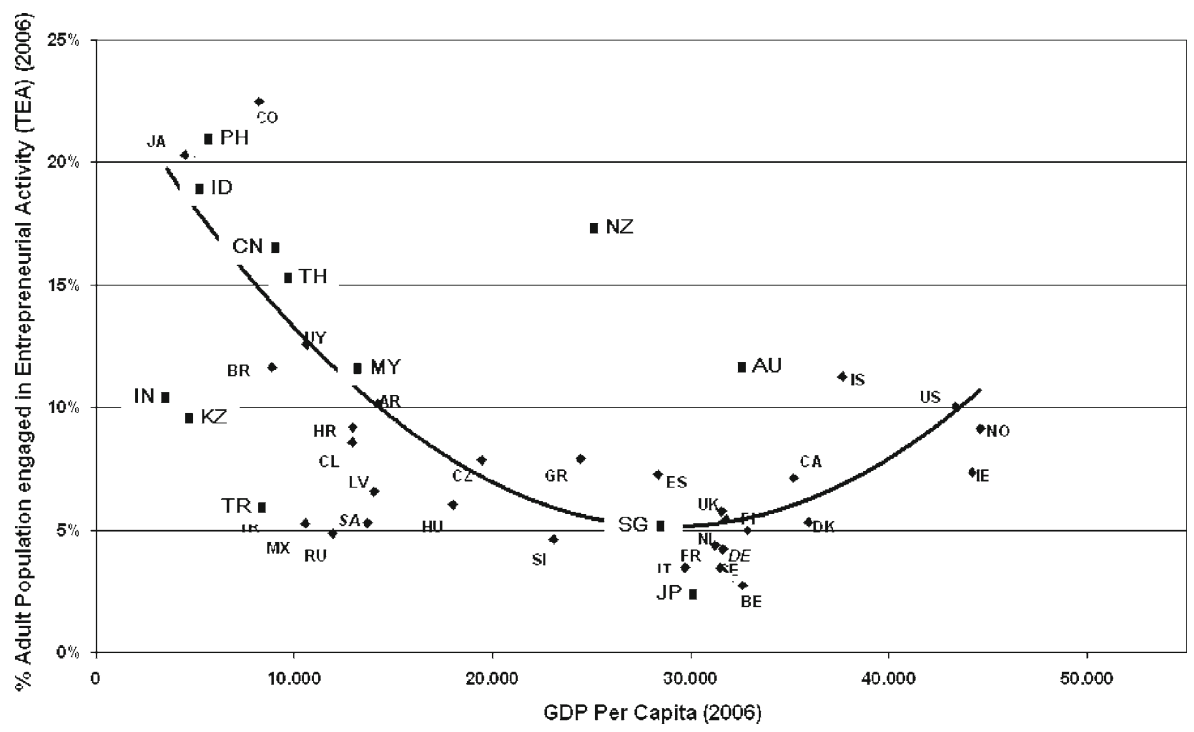

Note: Asian countries noted with larger text and bullet points; fitted polynomial ( $2^{\text {nd }}$ order). Source: GEM (2006), WEF (2007).

Figure 1 Total entrepreneurial activity and economic development 


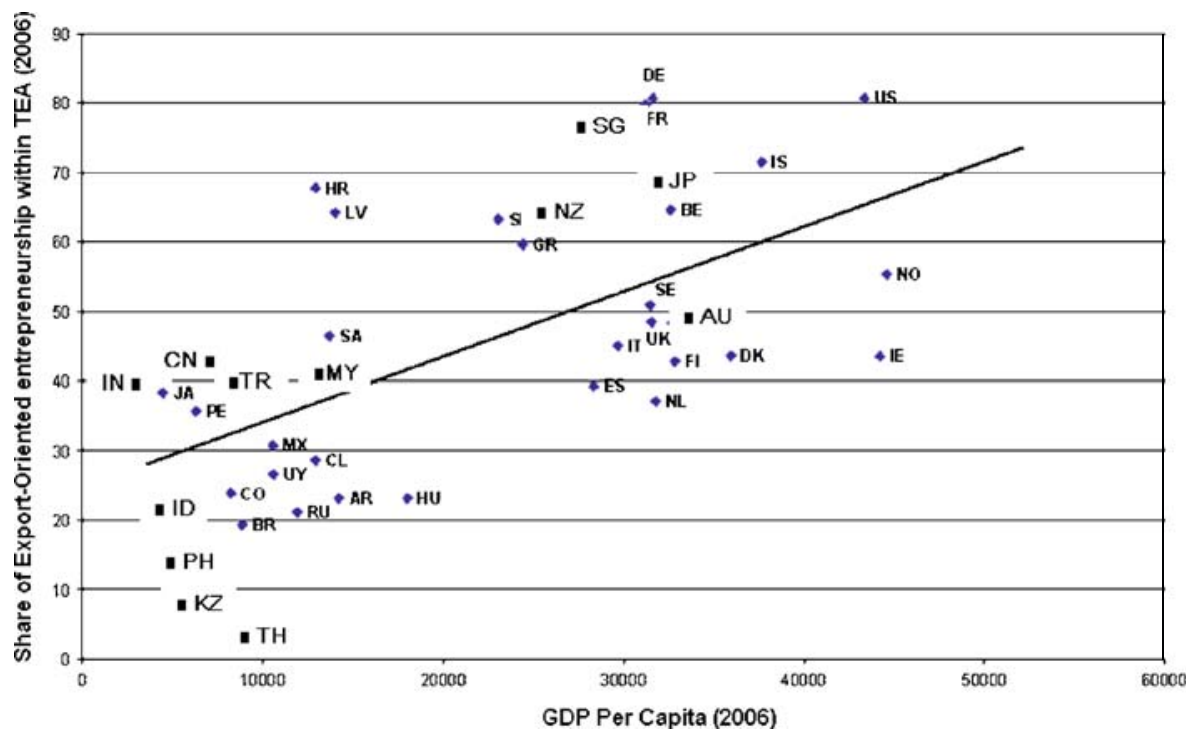

Note: Asian countries noted with larger text and bullet points; fitted trend line.

Source: GEM (2006), WEF (2007).

Figure 2 Export-oriented entrepreneurial activity and economic development

entrepreneurial efforts by indigenous populations in poor countries may not actually enhance those countries' economic development (Autio, 2007). Rather, economic development gains can only be realized from entrepreneurship which is innovative and spills over from the knowledge-based assets of large firms. Indeed, over the last three decades, OECD countries have gradually transitioned from "managed economies" dominated by large companies with mass production, differentiated products and massive economies of scale to "entrepreneurial economies" characterized by smaller firms which rely heavily upon knowledge, initiative and flexibility (Acs \& Audretsch, 2000). ${ }^{5}$ Figure 2 depicts the relationship between GDP per capita and export-oriented entrepreneurship in the same countries. As seen in Figure 2, countries with higher levels of development are more likely to have export-focused start-ups, although the direction of causality is not tested.

\section{Export-oriented entrepreneurial activity in Asia}

To compete in a global world, Asian countries must be able to develop and sustain locally-created, innovation-intensive firms. As shown, countries with high levels of overall entrepreneurial activity often do not have high levels of export-intensive activity. Note the stark differences between Figures 1 and 2 in terms of the scope of all entrepreneurial activity and that which is export-oriented. For example, Japan has $3 \%$ entrepreneurial activity but about $68 \%$ export-oriented entrepreneurial activity.

\footnotetext{
${ }^{5}$ For example, Ireland's economic development is partly driven by new firms started from knowledge spillovers from large multinational firms' knowledge-intensive activities (Acs, O'Gorman, Szerb, \& Terjesen, 2007).
} 
In our sample, the relationship between export-oriented entrepreneurial activity and economic development is quite linear. For example, New Zealand's GDP is approximately $\$ 52,000$ and $67 \%$ of New Zealand early-stage entrepreneurial firms seek foreign markets while the Philippines has a GDP of $\$ 5,000$ (10\% of New Zealand's) and only $15 \%$ of early-stage entrepreneurs have international markets (about $21 \%$ of New Zealand's total). (See Figure 2.) Countries with relatively high levels of GDP per capita are more likely than low income countries to have earlystage firms with a focus on exports.

From a strategy perspective, firms are actors that seek to develop resources into distinctive competencies and sustainable dynamic capabilities in order to produce and market goods (and services) profitably. To be able to export, firms must engage in value-added activities - that is be able to produce goods and services which are valued by foreign customers and at a profitable margin. Thus, firms must possess an efficient internal organization as well as a coordinated set of effective external relationships. For new firms, the transaction costs of doing business overseas are greater than in domestic markets (Zacharakis, 1997). ${ }^{6}$ Another critical consideration is that firms with high expectations for growth and exports are often started by entrepreneurs who had secure job prospects elsewhere, but decided to pursue more risky entrepreneurial endeavors (Acs \& Audretsch, 2000). We now explore the relationship between five sets of $\mathrm{VoC}$ institutions and export-oriented entrepreneurial activity.

\section{VoC: Institutional spheres}

\section{Industrial relations}

Firms must be able to recruit, organize and retain a labor force. Employees' efforts are compensated with salary and benefits. Wage compensation structures can vary along a spectrum set by the state (centralized bargaining process involving employer federations and unions) or left flexible at the discretion of firm managers and employees. The impact of wage compensation structures on the creation of new ventures is not clear, however several possible directions can be entertained. This is because export-oriented ventures frequently require a range of talent from lowskilled workers to highly-skilled workers in top management team leadership who are all impacted by wage compensation institutions.

In terms of unskilled labor, strong unions and collective wage bargaining in some regions, especially in Europe, can raise the wages, especially of low-skilled labor, to levels which firms may be unable to meet. This effect may be particularly strong for nascent entrepreneurs and new ventures attempting to establish themselves. High unemployment rates, especially in Europe, are often attributed to wage compensation institutions. The unemployed may seek other ways to enter the labor market,

\footnotetext{
${ }^{6}$ In additional to exporting, other means of new and incumbent firms' international entrepreneurship include licensing, franchising and foreign direct investment (FDI), however these entry modes are outside the scope of this study.
} 
including entrepreneurship, although their ventures may not necessarily be exportoriented. Collective bargaining is prevalent in other regions, however these salaries may be kept lower, better enabling firms to hire and retain a workforce. As exportoriented manufacturing sectors frequently rely upon low wages and high levels of control, agreements that set wages at achievable rates may lead to greater numbers of export-oriented ventures.

In contrast, countries can employ flexible wage compensation structures, enabling firms to tie individual compensation to productivity. An extensive body of management and economics research highlights this relationship: employees who are compensated for their productivity have a higher incentive and are more likely to be productive. Thus firms can reward and incentivize value-added activities by employees, including the creation of goods and services for overseas markets. More importantly, when business owners have more freedom to set wages, they can adjust wages according to different competitive environments which may also be important for enabling exports. However, some employees may not feel that they are properly compensated and may leave to establish their own firms (Acs \& Audretsch, 2000), which can vary in export orientation. Although the relationship between industrial relations and entrepreneurial activity rates is not clear cut, it is an important consideration, including for export-oriented new ventures.

\section{Vocational training and education}

A second major institutional sphere concerns the quality and quantity of vocational education and training. Firms derive their firm-specific, knowledge-based resources from the institutional environment and must be able to access a suitably skilled work force. Furthermore, a country's structure of education shapes attitudes towards work (Whitley, 1999; Redding, 2005).

Some countries enjoy an abundance of certain skill sets which can provide a comparative advantage for their national firms. For example, quality math and science skills facilitate the development of engineering and innovation (McAteer, 2007). Higher levels of education are reflected in greater quantities of knowledge capital and are likely to be positively related to the propensity to create products and services which can be exported. At the individual level, education is a key aspect of an entrepreneur's human capital and entrepreneurs who have higher levels of education are more likely to identify opportunities (Davidsson \& Honig, 2003) and have ambitions to grow their firms (Autio, 2007).

Other countries have very limited sets of human capital from which to draw from. Firms in these environments are constrained by this pool in terms of the goods and services it is possible to produce, including those for export. Firms that can access only limited resources in their environment are more likely to stay local in scope (Carney, 1998).

\section{Corporate governance}

The third institutional sphere, corporate governance, captures the ability of firms to access finance and of investors to capture returns on their investment (Hall \& Soskice, 2001) through the organization of corporate boards. Again, countries vary 
in the extent to which corporate governance institutions are held accountable which can impact entrepreneurial activity, including export orientation.

Highly efficacious corporate governance systems that consider the interests of various shareholders and have a culture of openness and disclosure of business information are more likely to attract potential investors. Firms with good corporate governance also yield higher valuations and returns, grow faster and, again, attract more investors. The firm managers can acquire knowledge from board members, stimulating a climate of openness and learning from other actors. Good corporate governance generates investors' goodwill and confidence, including future financing for the venture's international activities. Firms seeking innovation-based growth must be able to access patient capital in order to acquire strategic assets (Acs \& Audretsch, 2000; Carney \& Gedajlovic, 2000). Finance structures for acquiring and developing intangible assets (often required for international activities) are more complex, in part due to the limited collaterability of these assets.

In contrast, lower quality corporate governance systems can serve as a hindrance for firms. For example, countries and firms with less accountable corporate governance systems may be unable to attract capital at home or abroad. Corporate governance is particularly salient to Asia as traditionally Asian countries were characterized by personalized and relational corporate governance systems (La Porta, Lopez de Silanes, \& Shleifer, 1999) which did not formalize accountability and responsibility. Corporate governance systems have been held partly to blame for the financial crisis (Carney \& Gedajlovic, 2000). Many Asian entrepreneurs have resisted demands to include outsiders on their boards (Ahlstrom et al., 2004). Furthermore, Asia has a large bank sector; however banks are often ill-equipped to provide debt to new and small firms, particularly those pursuing high risk ventures (Carney \& Gedajlovic, 2000), as export-oriented ventures often are.

\section{Inter-firm relations}

Inter-firm relations constitute a fourth institutional sphere. New firms must be able to develop networks in both professional (e.g., other entrepreneurs, managers at key suppliers and buyers) and political (e.g., government officials) spheres. The ability to develop and the quality of these networks depends, in part, on the level of corruption in a country. Again, countries vary-some countries have transparent business systems which enable fair bidding on contracts, limit bribery and corruption and protect property rights. Other countries' business systems are characterized by high levels of organized crime, corrupt judiciary processes and other fraudulent systems.

Countries with high levels of corruption are generally associated with low levels of productivity and innovation. This is due, in part, to entrepreneurs' perceived inability to appropriate returns from their hard work. New ventures are particularly susceptible to the loss of intellectual property rights, especially when facing more established domestic multinationals and the domestic offices of foreign firms. Entrepreneurs operating in highly corrupt countries may decide not to start a venture due to these concerns and also may feel that they have more alternatives to utilizing their capital.

In contrast, countries with more transparent business systems often provide entrepreneurs with a range of achievable, merit-based business opportunities, including international opportunities. 
Employee relations

A final institutional pillar concerns the coordination problems with a firm's employees, focusing on the cooperative nature of employee relations. Management structures and processes are derived from the institutional environment (Hamilton \& Biggart, 1988). Employees with more freedom to access and implement new ideas are more likely to exploit new opportunities (Acs \& Audretsch, 2000). Cooperative employee relations regimes may also stimulate export-oriented new ventures as a skilled and proactive (entrepreneurial) labor force is more enabled to establish export-oriented firms.

Asian firms are characterized by strict control of decisions and information flow (Ahlstrom et al., 2004) which may be due to the limited supply of skilled middle managers. Such a structure inhibits creativity and may make it difficult for firm managers to work with younger, highly educated foreigners. Strict hierarchical environments may also inhibit the ability of entrepreneurs to innovate and to learn from other economic actors, and consequently may hamper their export opportunities.

Taken together, these five institutional pillars are expected to influence the prevalence and type of entrepreneurial activity.

\section{Data}

Data are derived from the 2006 and 2007 Global Entrepreneurship Monitor (GEM) survey of entrepreneurial activity and The Global Competitiveness Report 20052006 (GCR) of the World Economic Forum (WEF, 2007).

GEM was initiated in 1999 and has been expanded to over fifty national teams. The goals of the project are to measure differences in levels of entrepreneurial activity among countries, uncover factors that lead to appropriate entrepreneurship levels and suggest policies to enhance entrepreneurship. Each year GEM surveys, by telephone or door-to-door, representative population samples of between 1,000 and 42,000 randomly selected adults in each of the participating countries. The annual surveys are gathered between May and August, and the data is weighted to reflect the population (by age, gender, education, etc.) and harmonized with the other countries. GEM is widely acknowledged to be the best source of comparative entrepreneurship data in the world (Shorrock, 2008) and has been utilized in studies published in leading journals (e.g., Bowen \& De Clercq, 2008).

The principle GEM measure is Total early-stage Entrepreneurial Activity (TEA). TEA captures the percentage of the adult (aged 18-64) population that is actively involved in entrepreneurship in two populations: nascent entrepreneurs and young business owners. Nascent entrepreneurs are individuals who have, during the last 12 months, taken tangible action to start a new business, would personally own all or part of the new firm, would actively participate in the day-to-day management of the new firm and has not yet paid salaries for anyone for more than 3 months. Young business owners are defined as individuals who are currently actively managing a new firm, personally own all or part of the new firm and the firms in question are not more than 42 months old. In some cases, an individual may report both nascent and young business ownership activity, however this individual will only be counted 
once towards the TEA percentage in the adult population. TEA indices have high validity and reliability (Reynolds et al., 2005).

Within TEA, the present study is concerned with harmonized GEM measures for export orientation and utilizes two measures. First, early stage export orientation is defined as the percentage of entrepreneurs within TEA who report that at least $1 \%$ of their customers live overseas. Overall, according to the GEM measure, about half of the start-ups around the world expect to export. In our full country sample, across all countries, $46 \%$ of TEA entrepreneurs are at least $1 \%$ export-oriented. Second, we incorporate a measure of substantial export orientation which includes the percentage of entrepreneurs within TEA who report that at least $26 \%$ of their customers live abroad. Substantial export is more rare, averaging only $17 \%$ of TEA in our full sample.

We include data from the following countries: Argentina, Austria, Australia, Belgium, Brazil, Canada, Chile, China, Colombia, Croatia, Czech Republic, Denmark, Dominican Republic, Finland, France, Germany, Greece, Hungary, Iceland, India, Indonesia, Ireland, Israel, Italy, Jamaica, Japan, Kazakhstan, Latvia, Malaysia, Mexico, the Netherlands, Norway, Peru, Philippines, Portugal, Romania, Russia, Singapore, Slovenia, South Africa, Spain, Sweden, Switzerland, Thailand, Turkey, United Arab Emirates, United Kingdom, United States, Uruguay, Venezuela, and former Yugoslavia. (See Reynolds et al. (2005) for an extensive overview of GEM methodology and data and Levie and Autio (2008) for a theoretical grounding and test of the GEM model.)

As GEM measures are best used in combination with other data (e.g., Davidsson, 2004), we incorporate data from the Global Competitiveness Report (GCR) of the World Economic Forum (WEF, 2007) as independent variables and controls. As the economic environment can impact entrepreneurial activity and new ventures export orientation across countries (De Clercq, Hessels, \& van Stel, 2008; Wennekers \& Thurik, 1999), we include the following controls: GDP per capita, real exchange rate, inflation rate and prevalence of trade barriers. Furthermore, given the impact of the technological environment on entrepreneurship (Acs \& Audretsch, 2000), we include controls for FDI and technology transfer, prevalence of foreign technology licensing and firm-level technology absorption. We include dummies to capture year and Asian country. Table 1 provides an overview of our dependent, independent (the five institutional spheres) and control variables. Table 2 presents the levels of TEA and export-oriented TEA within the 12 Asian countries.

\section{Methodology}

We employ two empirical exercises. First, as our study is comparative, we graphically depict the relationship among the GEM substantial export shares and the five institutional spheres for each of the 12 Asian countries using a spider plot. $^{7}$

Our second test is a regression analysis with the dependent variables being GEM export orientation data from all countries. As noted above, GEM "export" is the

\footnotetext{
${ }^{7}$ Graphical depiction of VoC is consistent with earlier work by Hall and Soskice (2001) and others.
} 
Table 1 All variables: Measurement and source.

Measurement

Source (year)

Dependent variables
Export oriented entr.
activity
Substantial export
oriented entr. activity
Independent variables
Industrial relations

Vocational training \& education

Corporate governance

Inter-firm relations

Employee relations

Controls

GDP per capita

Real exchange rate

Inflation

Firm-level technology absorption

Prevalence of trade barriers

FDI and technology transfer

Prevalence of foreign technology licensing

Asia country dummy

Year dummy
Percent of total population of entrepreneurs (TEA) who report GEM, that $1-100 \%$ of product/service is for overseas customer

2006-2007

Percent of total population of entrepreneurs (TEA) who report GEM, that $26-100 \%$ of product/service is for overseas customer 2006-2007

"Wages in your country are $1=$ set by a centralized bargaining process; 7 = up to each individual company"

EOS, WEF, GCR 20052006

"Math and science education in your country's schools 1 = lag far behind most other countries; $7=$ are among the best in the world"

EOS, WEF, GCR 20052006

EOS, WEF, GCR 2005directors in your country is characterized by $1=$ management has little accountability; $7=$ investors and boards exert strong supervision of management decisions"

Index of the following: independence of the judiciary, fair bidding on public contracts, impact of organized crime on business; perception of existence of bribery and corruption within the economy

"Cooperation in labor-employer relations in your country are 1 = generally confrontational; 7 = generally cooperative"

2006

EOS, WEF, GCR 20052006

EOS, WEF, GCR 20052006

GDP per capita in US dollars, measured at Purchasing Power Parity 2004

WEF, GCR 2005-2006

Real effective exchange rate 2004 relative to the 1997-2003 average

WEF, GCR 2005-2006

Percentage change in consumer price index 2004

WEF, GCR 2005-2006

"Companies in your country are $1=$ not able to absorb new technology, 7 = aggressive in absorbing new technology"

EOS, WEF, WCY 20052006

"In your country, tariff and nontariff barriers significantly reduce the ability of imported goods to compete in the domestic market, 1 = strongly agree, 7 = strongly disagree"

EOS, WEF, GCR 20052006

FDI in your country $1=$ brings little new technology, $7=$ is an important source of new technology"

EOS, WEF, GCR 20052006

"In your country, licensing foreign technology is $1=$ uncommon, 7 = a common means of acquiring new technology"

EOS, WEF, GCR 20052006

"1 = Asian country (Australia, China, India, Indonesia, Japan, Kazakhstan, Malaysia, New Zealand, Philippines, Singapore, Thailand, Turkey); $0=$ other"

" $1=2007 ; 0$ = other" 
Table 2 Entrepreneurship in Asia: TEA and shares of export orientation.

\begin{tabular}{|c|c|c|c|c|c|}
\hline & $\begin{array}{l}\text { TEA, } \\
\% \text { of adult } \\
\text { population }\end{array}$ & $\begin{array}{l}\text { Export-oriented } \\
\text { entrepreneurship, } \\
\% \text { within TEA }\end{array}$ & $\begin{array}{l}\text { Export-oriented } \\
\text { entrepreneurship, } \\
\% \text { of adult } \\
\text { population }\end{array}$ & $\begin{array}{l}\text { Substantial } \\
\text { export-oriented } \\
\text { entrepreneurship, } \\
\text { \% within TEA }\end{array}$ & $\begin{array}{l}\text { Substantial } \\
\text { export-oriented } \\
\text { entrepreneurship, } \\
\% \text { of adult } \\
\text { population }\end{array}$ \\
\hline Australia & 11.9 & 48.3 & 5.7 & 13.0 & 1.6 \\
\hline China & 16.2 & 39.8 & 6.4 & 5.2 & 0.8 \\
\hline India & 10.4 & 38.8 & 4.0 & 16.5 & 1.7 \\
\hline Indonesia & 19.3 & 22.1 & 4.3 & 16.9 & 3.3 \\
\hline Japan & 2.9 & 67.9 & 2.0 & 0 & 0 \\
\hline Kazakhstan & 9.36 & 27.2 & 2.5 & 8.3 & 0.8 \\
\hline Malaysia & 11.1 & 42.4 & 4.7 & 9.2 & 1.0 \\
\hline $\begin{array}{l}\text { New } \\
\quad \text { Zealand }\end{array}$ & 17.6 & 61.9 & 10.9 & 10.5 & 1.8 \\
\hline Philippines & 20.4 & 15.0 & 3.1 & 2.5 & 0.5 \\
\hline Singapore & 4.9 & 77.5 & 3.8 & 34.8 & 1.7 \\
\hline Thailand & 15.2 & 2.7 & 0.4 & 1.2 & 0.2 \\
\hline Turkey & 6.1 & 38.8 & 2.4 & 17.4 & 1.1 \\
\hline
\end{tabular}

percentage of early stage entrepreneurs who have indicated that at least one percent of their customers live abroad. GEM "substantial export" denotes the percentage of early-stage entrepreneurs for whom more than a quarter of their customers live abroad. Since not all countries participated in both 2006 and 2007, the dataset is an unbalanced panel containing 83 observations.

\section{Results}

Asian countries: Spider plot of five institutional spheres

Figure 3 shows the vast heterogeneity across countries in terms of substantial export orientation and the five institutional spheres. The following four Asian countries' unique institutional environments are highlighted: Australia, Japan, Philippines, and Singapore.

\section{Regression on all countries}

Thus far, we employ simple descriptive statistics of the relationship among the five institutional spheres and new venture exports. It is necessary to examine whether these relationships will hold when incorporating all $\mathrm{VoC}$ variables simultaneously. To do so, we carry out regression analyses. Table 3 shows the correlations among variables in the regression analyses for our 83 observations. As seen in Table 3, some relationships between independent variables are correlated above 0.5 , raising concerns about multicollinearity. However, multicollinearity tests using variance 


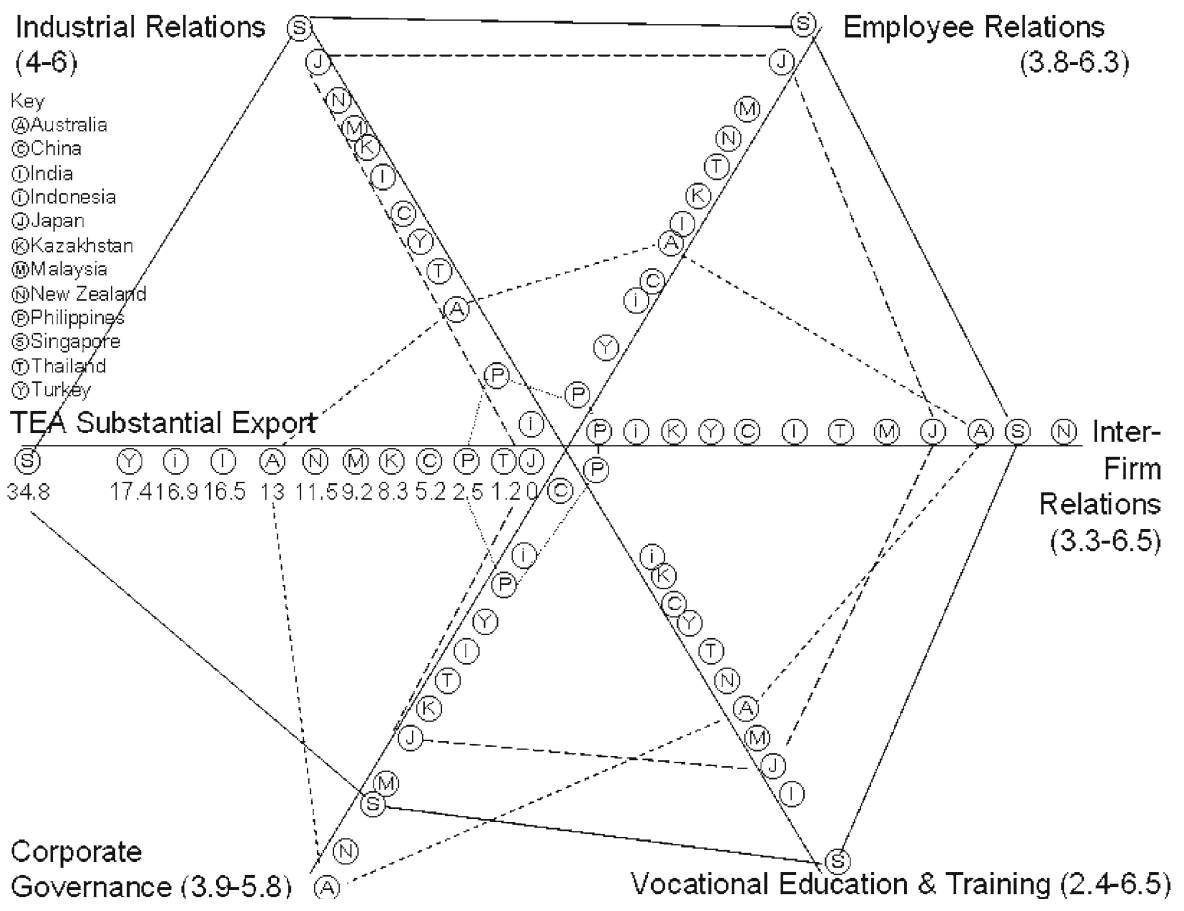

Note: Graphical depiction of Australia, Japan, Philippines and Singapore.

Source: GEM (2007), WEF (2007).

Figure 3 Export-oriented entrepreneurship and VoC institutions

inflation factors (VIFs) indicate that multicollinearity is not a concern in our regression models since VIFs are well below 10 (the highest VIF observed is 4.307).

Hierarchical regression results are presented in Table 4. Model 1 reports results when only control variables are included with export as the dependent variable and model 3 reports results when only controls are included with substantial export as the dependent variable. Models 2 and 4 report results with the inclusion of the $\mathrm{VoC}$ variables. The results reveal that there is a substantial increase in model fit in model 2 (as compared to model 1) and in model 4 (as compared to model 3) when the $\mathrm{VoC}$ variables are included.

With respect to the control variables, model 1 of Table 4 reveals that a higher level of GDP per capita is associated with higher proportions of early-stage ventures with an export focus, whereas model 3 indicates that a lower prevalence of trade barriers is significantly positive related to a substantial export orientation (and this holds in model 4 when the $\mathrm{VoC}$ variables are included), but has no impact on export in general (see models 1 and 2). When all variables (both the control variables and the $\mathrm{VoC}$ variables) are included (in models 2 and 4) then both GDP per capita and the prevalence of foreign technology licensing relate positively to both export and substantial export.

The results in models 2 and 4 also show a significant negative association between the Asian country dummy and both dependent variables: export and substantial export. This finding provides empirical support to the notion that 


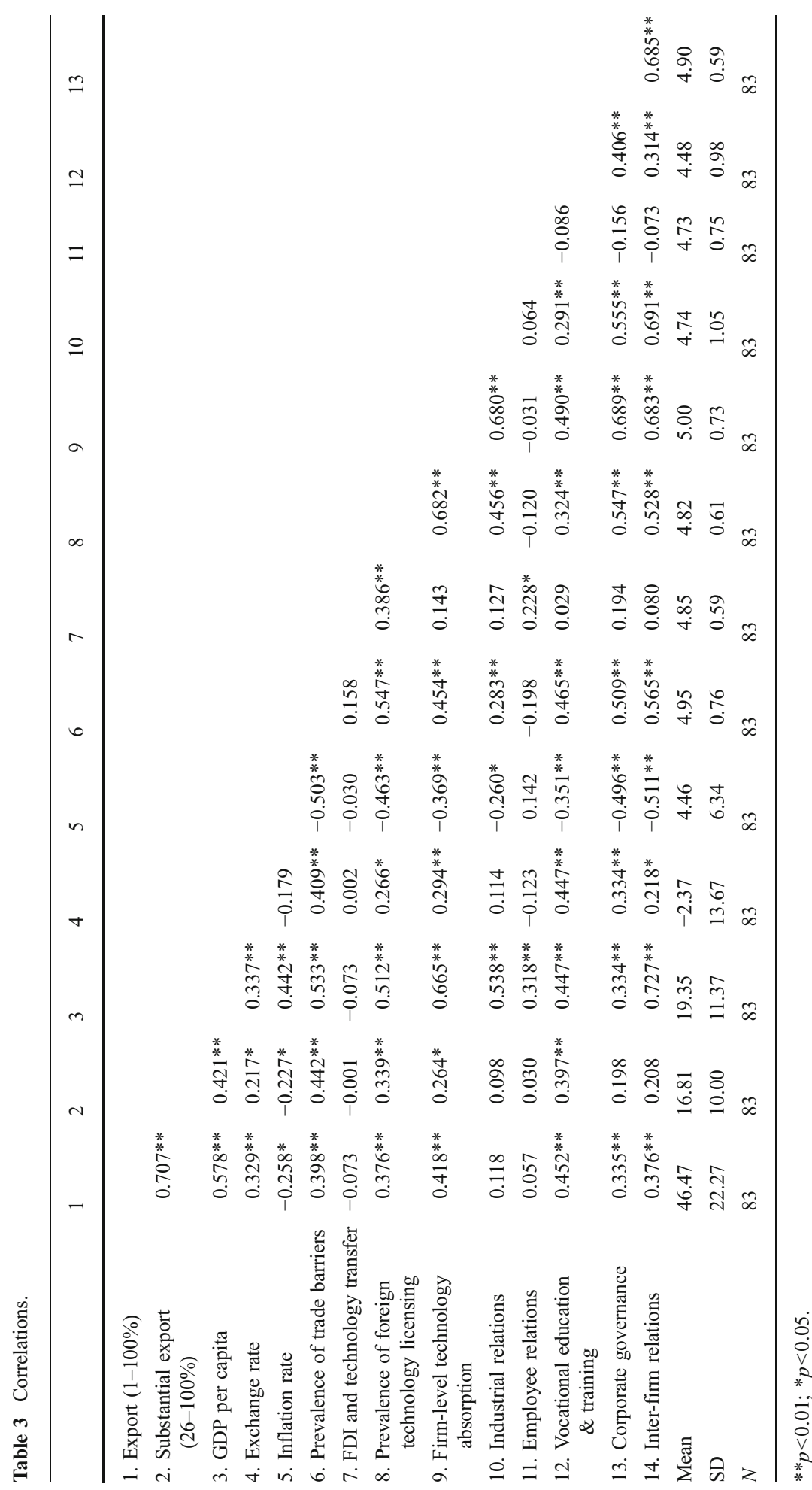


Table 4 Regression results.

\begin{tabular}{|c|c|c|c|c|}
\hline & \multicolumn{2}{|l|}{ DV: Export } & \multicolumn{2}{|c|}{ DV: Substantial export } \\
\hline & Model 1 & Model 2 & Model 3 & Model 4 \\
\hline Constant & $6.270(0.232)$ & $-3.591(-0.137)$ & $-8.120(-0.620)$ & $-12.134(-0.857)$ \\
\hline GDP per capita & $0.699 *(2.149)$ & $1.127 * *(3.804)$ & $0.236(1.493)$ & $\begin{array}{r}0.429 * * \\
(2.682)\end{array}$ \\
\hline Exchange rate & $0.193(1.155)$ & $0.049(0.345)$ & $0.007(0.082)$ & $-0.056(-0.731)$ \\
\hline Inflation rate & $0.203(0.531)$ & $0.227(0.648)$ & $0.121(0.624)$ & $0.008(0.043)$ \\
\hline Year dummy 2007 & $-2.025(-0.486)$ & $-4.352(-1.292)$ & $1.370(0.678)$ & $0.338(0.185)$ \\
\hline Prevalence of trade barriers & $1.981(0.528)$ & $-0.310(-0.096)$ & $3.840 *(2.108)$ & $3.886 *(2.233)$ \\
\hline $\begin{array}{l}\text { FDI and technology } \\
\text { transfer }\end{array}$ & $-4.598(-1.126)$ & $-6.226(-1.786)$ & $-1.481(-0.747)$ & $-2.081(-1.104)$ \\
\hline $\begin{array}{l}\text { Prevalence of foreign } \\
\text { technology licensing }\end{array}$ & $7.224(1.233)$ & $13.954 * *(2.830)$ & $4.386(1.542)$ & $\begin{array}{r}7.177 * * \\
(2.692)\end{array}$ \\
\hline $\begin{array}{l}\text { Firm-level technology } \\
\text { absorption }\end{array}$ & $1.271(0.268)$ & $4.083(0.887)$ & $-2.702(-1.172)$ & $-1.588(-0.638)$ \\
\hline Asian country dummy & $-6.741(-1.056)$ & $-14.958 * *(-2.582)$ & $-1.339(-0.432)$ & $\begin{array}{r}-6.672 * * \\
(-2.130)\end{array}$ \\
\hline \multicolumn{5}{|l|}{ VoC variables } \\
\hline $\begin{array}{l}\text { Industrial relations: } \\
\text { flexible wages }\end{array}$ & & $8.833^{* *}(4.873)$ & & $\begin{array}{r}3.330 * * \\
(3.398)\end{array}$ \\
\hline $\begin{array}{l}\text { Vocational training } \\
\text { \& education: math } \\
\text { and science }\end{array}$ & & $6.661 * *(2.899)$ & & $2.853 *(2.297)$ \\
\hline $\begin{array}{l}\text { Corporate governance: } \\
\text { efficacious boards }\end{array}$ & & $-10.171(-1.979)$ & & $-4.973-1.790$ \\
\hline $\begin{array}{l}\text { Inter-firm relations: fair } \\
\text { bidding, transparency }\end{array}$ & & $1.808(0.509)$ & & $-3.283(-1.709)$ \\
\hline $\begin{array}{l}\text { Employee relations: } \\
\text { cooperative }\end{array}$ & & $-11.435^{* *}(-3.223)$ & & $-0.391(-0.204)$ \\
\hline R2 (adjusted) & 0.308 & 0.565 & 0.191 & 0.369 \\
\hline Obs & 83 & 83 & 83 & 83 \\
\hline
\end{tabular}

$t$-values between parentheses.

$* * p<0.01 ; * p<0.05$.

compared to non-Asian countries, Asian countries' early-stage ventures are significantly less likely to focus on exports $(p<0.01)$.

With regard to our $\mathrm{VoC}$ institutions (see models 2 and 4 of Table 4), we find the following results:

First, flexible industrial relations are significantly positive related to export and to substantial export $(p<0.01)$. When we include interaction terms of the Asian country dummy with our indicators for industrial relations, we find that this term is not significant, indicating that results for Asia are in accordance with the pattern for all countries. (We do not report this or other interactions in the paper.)

Second, and also in accordance with the spider plot for Asia (Figure 3), we find that quality vocational education and training is also significantly positive, both for 
export $(p<0.01)$ and substantial export $(p<0.05)$. This is in line with the overall pattern that we observe for Asian countries.

Third, the institution of quality corporate governance, as measured by efficacy of corporate boards, is negatively associated with export though not significant. Thus, while we would expect a positive relationship between the quality of corporate governance and export based on the spider plot of the Asian countries, this pattern is not confirmed when all $\mathrm{VoC}$ variables, controls and countries are included in the analysis. We also employed an interaction term between the Asian country dummy and corporate governance to investigate whether results for Asia deviate from those of other countries (not reported in the table), but do not find any indication that this is the case.

Fourth, for the inter-firm (public) institutions index, we find no significant relationship with our dependent variables. Thus, from the Asian countries' spider plot, we expected a positive relationship between the quality of public institutions and export orientation, but this relationship does not hold when the other $\mathrm{VoC}$ variables, control variables and all countries are included in the analysis. Again, we included an interaction term between the Asian country dummy and the public institution index (not reported) to see whether the pattern for Asian countries deviates from this general pattern, but we do not find any evidence of this.

Finally, and surprisingly, we find that cooperative employee relations are negatively related to export orientation, although the relationship is non-significant in the case of substantial export. When we include an interaction term between the Asian country dummy and our variable for employee relations, the result for Asian countries does not deviate from this overall pattern.

In sum, based on the regressions with the inclusion of several control variables and in which we include all $\mathrm{VoC}$ variables simultaneously, we find that the new venture export is significantly predicted by institutions related to flexible industrial relations, quality vocational education and training, and by confrontational laboremployer relations (no impact on substantial export). However, the proportion of new venture exporters is not impacted by corporate governance and by the overall quality of inter-firm (public) institutions.

\section{Discussion}

This study explores how institutional structures relate to new firm entrepreneurship and in particular, to export orientation with a specific focus on Asia. Data from 51 countries suggests that prevailing institutions play a role in inhibiting or facilitating export-oriented entrepreneurship among young firms. Specifically, our findings suggest that countries have higher proportions of export-oriented entrepreneurial activity when industrial relations are more flexible, training institutions are of high quality, and labor-employer relations are confrontational. However, the proportion of export-oriented new ventures is not affected by the quality of corporate governance and inter-firm (public) institutions. That export orientation is not affected by corporate governance may be because these emerging export-oriented ventures may be founded and funded by close-knit groups, such as family and ethnic minority business groups. 
Differences in institutional environments generate differences in strategy across countries, including export-orientation of business activities. Furthermore, Asian countries are less likely than the other countries in our sample to have exportoriented entrepreneurs. Nevertheless, there is clear variation also between Asian countries. As seen in Figure 2, three Asian countries have the world's lowest proportions of export-oriented entrepreneurial activity: Thailand, Kazakhstan and the Philippines. The tremendous variation is clear, though New Zealand and Australia (two of the LMEs), Japan (a classic CME) and Singapore (a mixed market economy) deliver the highest shares of export-oriented entrepreneurship. Why might this be the case? Indeed, it is worth commenting on the unique endowments of these outliers.

The Japanese business environment is populated by keiretsus, families of companies with dense connections, often with one major company (e.g., Toyota) at the epicenter. Inter-firm cooperation and coordination takes place within the keiretsu. For example, a small parts supplier for Toyota in Japan might follow Toyota to the United States, setting up operations alongside an automobile manufacturing plant in Kentucky. At the individual level, employees in Japanese firms are encouraged to develop skills that meet firm or keiretsu needs. The longstanding employment contracts can result in focusing on venture-related skills for firms in these keiretsu groups.

Modern Australia is considered a classic LME economy, characterized by hierarchical $\mathrm{m}$-form diversified firms, strong emphasis on competition and antitrust, decentralized wages and highly competitive labor markets (Parker, 2002). Indeed, the Australian government has, for over a decade, pursued small business policy to encourage entrepreneurship, including export-oriented programs such as Export Market Development Grants (Parker, 2002; Austrade, 2008). Australia's market relations approach to small business policy is consistent with the institutions of competitive business systems (Parker, 2002) and has resulted in dynamic business outcomes.

As illustrated in most of the analyses, Singapore has sample-leading institutions in terms of lack of corruption, highly flexible wages and cooperative employee relations, excellent math/science and efficacious corporate governance. Singapore has long-dominated the region's high end manufacturing and illustrates a path dependent trajectory, particularly in the electronics industry.

Despite the country-variations in export-oriented entrepreneurial activity and institutional structures, we do find some overall patterns across all countries for the impact of institutions on both export orientation in general and on high export. For example, the findings highlight the importance of high quality vocational education and training systems for promoting export-oriented entrepreneurship. The Philippines score rather low on the quality of vocational education and training, but Indonesia, Kazakhstan, China and Turkey also lag behind on this index. The results also confirm that wage compensation structures can enable or constrain exportoriented entrepreneurship. In particular, when countries have a system in which wages are set by individual companies - as opposed to central bargaining - this benefits export-oriented entrepreneurship. The Philippines and Indonesia stand out as countries with central bargaining systems. Above we outlined a number of reasons for why flexible systems may favor export activity, i.e., that in such a flexible system employees are likely to have a higher incentive to be productive 
(since they can be rewarded in terms of higher wages) and that business owners have more freedom to adjust wages to different competitive environments. Compared to central bargaining environments, a new venture in a flexible wage system environment is likely to be surrounded by productive, highly competitive firms and may need to be extremely efficient, including export behavior.

Returning to the full picture of export-oriented entrepreneurial activity in Figure 2, what might be suggested for countries like Thailand, Kazakhstan and the Philippines with some of the lowest GDPPCs and some of the lowest proportions of exportoriented entrepreneurial activity in the world? It is tempting to suggest the revision of particular institutions to those that are more conducive to export-oriented entrepreneurship and also economic development. While public policy is certainly an aspect of the five institutional VoC pillars, existing institutions also constitute a limitation on policy as institutions are path dependent (Parker, 2002). Government policies that are too ambitious and completely incompatible with the institutional environment will not succeed.

We acknowledge several limitations of our study. First, we examine only a limited range of data for each of the five national institutional factors and future studies could seek to incorporate additional proxies for the institutional spheres of VoC. However, as much VoC literature is limited to theorizing about possible impacts, we believe our cross-country comparative study is a useful extension in that we gather and report actual relationships in data from a large set of Asian and non-Asian countries. Although we examine many institutions and included relevant controls in our regressions, there may be other factors such as the extent of national security, military regimes, venture capital, information-hoarding culture, fear of failure, family business, Confucianism and information asymmetry which may be important for explaining export, particularly in Asia (e.g., Ahlstrom et al., 2004; Begley \& Tan, 2001; Carney \& Gedajlovic, 2000; Chung, Shepard, \& Dollinger, 1989; Haggard, 2004; Steier, 2009; Yeung, 2002).

\section{Conclusions and implications}

In conclusion, our study suggests that prevailing institutional structures influence the proportion of export-oriented entrepreneurial activity in Asia and elsewhere in the world. In accordance with $\mathrm{VoC}$ we find that national institutions affect firm behavior and in particular firm export. However, while $\mathrm{VoC}$ would predict that variety in national institutional set-ups can result in similar outcomes for firm behavior among nations, our results suggests that a linear relationship exists between the quality of a country's institutions and new venture export (i.e., the relation is positive for industrial relations and education and negative for labor-employer relations). We acknowledge the possibility of a circuitous relationship here that exports help build institutional environments. Furthermore, institutions are highly embedded and there are interrelationships among institutional structures. Export-oriented activities may be concentrated in certain sectors such as electronics in Singapore and software development in India.

Firms and national institutional path dependencies shape Asian entrepreneurs' abilities to seize international market opportunities. As new ventures seek 
international markets, they may grow into large multinationals. This transition is part of the ever-changing landscape of institutional factors. Indeed, firms and institutional change are co-evolutionary.

Our study suggests a number of directions for future research. First, as shown in Figure 3, there are heterogeneous sets of institutions that are related to exportoriented entrepreneurial activity. Future research could explore the complementarity of sets of institutions. A second strand of enquiry could examine other key, but oftoverlooked institutions in Asia such as familial capitalism (Steier, 2009). Third, further research of a longitudinal nature could examine the change in $\mathrm{VoC}$ and export-oriented entrepreneurial activity over time. For example, it could be interesting to explore the exact channels by which flexible wage structures might favor export-oriented entrepreneurial activity. The eight "emerging" countries in the present study may be particularly susceptible to vast changes in the immediate future. Furthermore, as Peng (2003) suggests, these changes may enhance new firms' market-focused competitive strategies and reduce incumbent firms' ability to operate from traditionally relational strategies. Fourth, there are obvious extensions to examine other Asian countries and certain populations. One potential line of enquiry lies in the extent and organization of ethnic Chinese populations in Asian countries. These minorities, while comprising a small percentage of Asian countries' populations outside China, nevertheless dominate the private firm sector (Dana, 2007). Although most institutional structures operate at the national level (Hall \& Soskice, 2001), further studies could focus on city and regional level institutions. For example, agglomerations may play a role; regions with high levels of exportintensive industries are more likely to have higher endowments of resources which early-stage firms can access. There may also be city or regional differences such as special enterprise zones and science parks which are somewhat isolated from traditional national institutional environments (Karlsson, 2005). Studies could also be framed using the practice theory of entrepreneurship, considering individual and firm interpretations of the institutional environment. Outliers could also be researched. For example, at the firm level, there is anecdotal evidence from Hong Kong's VTech that a high-growth, globally-focused firm can succeed by creating structures not generally found in Asia (Ahlstrom et al., 2004). Finally, extensions could be made to other types of entrepreneurial activity, such as the provision of informal and formal venture capital.

We also hope our findings will be of interest to public policy makers. We are not espousing policy to promote entrepreneurial activity in general, but more specifically new entrants with export potential. We believe that government policy must address a range of institutional policies and be well-coordinated and compatible with existing environments to be effective. Our findings suggest the importance of policy at multiple levels to encourage individuals who have the ability to start export-oriented firms, facilitate the growth of these firms, and create a supportive industry and national environment. These levels include the individual (e.g., math and science education in school), firm (flexible wages) and state (prevalence of foreign technology licensing, GDP per capita). It is also important to distinguish quantity and quality in policy directives. As shown in Table 2, in Asia, high levels of entrepreneurial activity are not associated with high proportions of export-oriented entrepreneurial activity. Targeting quantity, rather than quality, may be counterproductive (van Stel \& Storey, 2004). 
Open Access This article is distributed under the terms of the Creative Commons Attribution Noncommercial License which permits any noncommercial use, distribution, and reproduction in any medium, provided the original author(s) and source are credited.

\section{References}

Acs, Z., \& Audretsch, D. B. 2000. Innovation and small firms. Cambridge: MIT.

Acs, Z., \& Terjesen, S. 2007. Born local: Two views of internationalization. Jena economic research paper no. 2007-022, Friedrich-Schiller-University Jena, Max-Planck-Institute of Economics, Jena, Germany.

Acs, Z., O’Gorman, C., Szerb, L., \& Terjesen, S. 2007. Could the Irish miracle be repeated in Hungary?. Small Business Economics, 28(2/3): 123-142.

Ahlstrom, D., Young, M. N., Chan, E. S., \& Bruton, G. D. 2004. Facing constraints to growth? Overseas Chinese entrepreneurs and traditional business practices in East Asia. Asia Pacific Journal of Management, 21: 263-285.

Allen, M. 2004. The VoC paradigm: Not enough variety?. Socio-Economic Review, 2: 87-108.

Andriesse, E., \& van Westen, G. 2009. Comparative institutional advantages along the Thai-Malaysian border? The role of institutional complementaries in regional development. Asia Pacific Journal of Management, 26 (Special Issue). doi:10.1007/s10490-008-9107-2.

Austrade. 2008. Review of export policies and programs. Issue paper, Department of Foreign Affairs and Trade, Australia

Autio, E. 2007. Global entrepreneurship monitor (GEM) high-expectation entrepreneurship. London Business School and Babson College.

Autio, E., \& Acs, Z. 2008. Individual and country-level determinants of entrepreneurial growth aspirations. Working paper, GEM Research Conference, Washington, DC.

Autio, E., Sapienza, H. J., \& Almeida, J. G. 2000. Effects of age at entry, knowledge intensity, and imitability on international growth. Academy of Management Journal, 43(5): 909-924.

Baker, T., Gedajlovic, E., \& Lubatkin, M. 2005. A framework for comparing entrepreneurship processes across nations. Journal of International Business Studies, 36: 493-513.

Baumol, W. 1990. Entrepreneurship: Productive, unproductive and destructive. Journal of Political Economy, 98(5): 893-921.

Begley, T. M., \& Tan, W. I. 2001. The socio-cultural environment for entrepreneurship: A comparison between East Asian and Anglo-Saxon countries. Journal of International Business Studies, 32(3): 537-553.

Bowen, H. P., \& De Clercq, D. 2008. Institutional context and the allocation of entrepreneurial effort. Journal of International Business Studies, 39: 747-767.

Carney, M. 1998. A management capacity constraint? Obstacles to the development of the overseas Chinese family business. Asia Pacific Journal of Management, 15(2): 137-162.

Carney, M. 2004. The institutions of industrial restructuring in Southeast Asia. Asia Pacific Journal of Management, 21(1-2): 171-188.

Carney, M., \& Gedajlovic, E. 2000. East Asian financial systems and the transition from investment-driven to innovation driven economic development. International Journal of Innovation Management, 4(3): 253-276.

Carney, M., \& Gedajlovic, E. 2003. Strategic innovation and the administrative heritage of East Asian Chinese family business groups. Asia Pacific Journal of Management, 20: 5-26.

Chung, C. H., Shepard, J. M., \& Dollinger, M. J. 1989. Max Weber revisited: Some lessons from East Asian capitalistic development. Asia Pacific Journal of Management, 6(2): 307-321.

Clarke, S., Lee, C.-H., \& Li, Q. 2004. Collective consultation and industrial relations in China. British Journal of Industrial Relations, 42(2): 235-254.

Dana, L. P. 2007. Asian models of entrepreneurship. Singapore: World Scientific.

Davidsson, P. 1995. Culture, structure and regional levels of entrepreneurship. Entrepreneurship \& Regional Development, 7: 41-62.

Davidsson, P. 2004. Researching entrepreneurship. New York: Springer.

Davidsson, P., \& Honig, B. 2003. The role of social and human capital among nascent entrepreneurs. Journal of Business Venturing, 18: 301-331.

De Clercq, D., Hessels, J., \& van Stel, A. 2008. Knowledge spillovers and new venture's export orientation. Small Business Economics, 31(3): 283-303.

The Economist 2002. Science and technology: Biotech's yin and yang, 365(8303): 87. 
Elam, A., \& Terjesen, S. 2007. Institutional logics: Gender and business creation across 28 countries. Paper presented at Babson College Entrepreneurship Research Conference (BCERC), Madrid, Spain, June.

Fligstein, N. 2002. The architecture of markets: An economic sociology of twenty-first-century capitalist societies. Princeton: Princeton University Press.

Frenkel, S., \& Kuruvilla, S. 2002. Logics of action, globalization and changing employment relations in China, India, Malaysia and the Philippines. Industrial and Labor Relations Review, 55(3): 387-412.

Gartner, W. B. 1988. Who is the entrepreneur? Is the wrong question. American Journal of Small Business, 12(4): 11-32.

Global Entrepreneurship Model (GEM). 2006. GEM 2006 Data Set. http://www.gemconsortium.org/.

Global Entrepreneurship Model (GEM). 2007. GEM 2007 Data Set. http:/www.gemconsortium.org/.

Girma, S., Greenaway, D., \& Kneller, R. 2004. Does exporting increase productivity? A microeconometric analysis of matched firms. Review of International Economics, 12(5): 855-866.

Haggard, S. 2004. Institutions and growth in East Asia. Studies in Comparative International Development, 38(4): 53-81.

Hall, P. A., \& Soskice, D. 2001. Varieties of capitalism. Oxford: Oxford University Press.

Hall, P. A., \& Thelen, K. 2005. Institutional change in varieties of capitalism. Working paper presented at the International Sociological Association, Research Committee 19 Annual Conference, Chicago, IL, September.

Hamilton, G. G., \& Biggart, N. W. 1988. Market, culture, and authority: A comparative analysis of management and organization in the Far East. American Journal of Sociology, 94: 52-94.

Hawkins, D. I. 1993. New business entrepreneurship in the Japanese economy. Journal of Business Venturing, 8: 137-150.

Hessels, J., \& Terjesen, S. 2009. Resource dependency and institutional theory perspectives on direct and indirect export choices. Small Business Economics. doi:10.1007/s11187-008-9156-4.

Hessels, J., \& van Stel, A. 2007. Export orientation among new ventures and economic growth. ERIM (Erasmus Institute of Management) Report Series 2007-2008.

Johns, G. 2006. The essential impact of context on organizational behavior. Academy of Management Review, 31(2): 386-408.

Karlsson, T. 2005. Business plans in new ventures: An institutional perspective. Dissertation series, Jonkoping International Business School, Sweden.

Knowledge@wharton. 2007. At home and abroad, what value do non-resident Indians bring to multinational corporations?. http://knowledge. wharton.upenn.edu/india/article.cfm?articleid=4213, Accessed July 27.

Kuruvilla, S. 1998. Linkages between industrialization strategies and industrial relations/human resource policies: Singapore, Malaysia, the Philippines, and India. Industrial and Labor Relations Review, 49: 635-657.

La Porta, R., Lopez de Silanes, F., \& Shleifer, A. 1999. Corporate ownership around the world. Journal of Finance, 54(2): 471-517.

Levie, J., \& Autio, E. 2008. A theoretical grounding and test of the GEM model. Small Business Economics, 31(3): 235-263.

Lu, J. W., \& Beamish, P. W. 2001. The internationalization and performance of SMEs. Strategic Management Journal, 22(6/7): 565-586.

McAteer, M. 2007. Submission to Productivity Commission Study of Public Support for Science and Innovation in Australia, Productivity Commission. Australia.

McMullen, J. S., Bagby, D. R., \& Palich, L. E. 2008. Economic freedom and the motivation to engage in entrepreneurial action. Entrepreneurship Theory \& Practice, September: 875-895.

Meyer, K. 2006. Asian management research needs more self-confidence. Asia Pacific Journal of Management, 23(2): 119-137.

North, D. 1990. Institutions, institutional change and economic performance. Cambridge: Cambridge University Press.

Organization for Economic Cooperation and Development (OECD). 2003. Entrepreneurship and local economic development: Programme and policy recommendations. Paris: OECD.

Parker, R. 2002. Coordination and competition in small nusiness policy: A comparative analysis of Australia and Denmark. Journal of Economic Issues, 36(4): 935-952.

Peng, M. W. 2003. Institutional transitions and strategic choices. Academy of Management Review, 28(2): 275-296.

Redding, G. 2005. The institutions of human capital. Working paper no. 22, INSEAD.

Reynolds, P. D., Bygrave, W., \& Autio, E. 2004. GEM 2003 executive report. Babson College and London Business School. 
Reynolds, P., Bosma, N., Autio, E., Hunt, S., De Bono, N., Servais, I., Lopez Garcia, P., \& Chin, N. 2005. Global entrepreneurship monitor: Data collection design and implementation 1998-2003. Small Business Economics, 24(3): 205-231.

Ritchie, B. 2009. Economic upgrading in a state-coordinated, liberal market economy. Asia Pacific Journal of Management, 26 (Special Issue). doi:10.1007/s10490-008-9089-0.

Rugman, A. M., \& Wright, R. W. 1999. Research in global strategic management: International entrepreneurship. Stamford, CT: JAI.

Schumpeter, J. A. 1934. The theory of economic development. Cambridge: Harvard University Press.

Scott, W. R. 2005. Institutional theory: Contributing to a theoretical research paradigm. In K. G. Smith \& M. A. Hitt (Eds.). Great minds in management: 460-484. Oxford: Oxford University Press.

Shorrock, A. 2008. Opening address presented at the United Nations University-WIDER Conference on Entrepreneurship and Economic Development, Helsinki, Finland, August.

Steier, L. P. 2009. Familial capitalism in global institutional contexts: Implications for corporate governance and entrepreneurship in Asia. Asia Pacific Journal of Management, 26 (Special Issue), doi:10.1007/s10490-008-9117-0

Storey, D., \& Tether, B. 1998. Public policy measures to support new technology-based firms in the European Union. Research Policy, 26: 1037-1057.

Streeck, W., \& Yamamura, K. 2001. The origins of nonliberal capitalism: Germany and Japan. Ithaca and London: Cornell University Press.

Szerb, L., Terjesen, S., \& Rappai, G. 2007. Seeding new ventures: Green thumbs not fertile fieldsindividual and environmental drivers of informal investment. Venture Capital, 9(4): 1-27.

Taylor, M. Z. 2004. Empirical evidence against varieties of capitalism's theory of technological innovation. International Organization, 58(Summer): 601-631.

Terjesen, S., O'Gorman, C., \& Acs, Z. 2008. Intermediated internationalization: Evidence from the software industry in Ireland and India. Entrepreneurship \& Regional Development, 20(1): 89-109.

van Stel, A., \& Storey, D. 2004. The link between firm births and job creation: Is there a Upas tree effect?. Regional Studies, 38(8): 893-909.

Wennekers, A. R. M., \& Thurik, A. R. 1999. Linking entrepreneurship and economic growth. Small Business Economics, 13(1): 27-55.

Whitley, R. 1998. Internationalization and varieties of capitalism: The limited effects of cross-national coordination of economic activities on the nature of business systems. Review of International Political Economy, 5(3): 445-481.

Whitley, R. 1999. Divergent capitalism: The social structure and change of business systems. Oxford: Oxford University Press.

World Economic Forum (WEF). 2007. Global competitiveness report 2005-2006. Geneva, Switzerland: WEF.

Yang, X., \& Terjesen, S. 2007. In search of confidence: Context, collaboration, and constraints. Asia Pacific Journal of Management, 24(4): 497-507.

Yeung, H. W.-C. 2002. Entrepreneurship in international business: An institutional perspective. Asia Pacific Journal of Management, 19(1): 26-61.

Zacharakis, A. 1997. Entrepreneurial entry into foreign markets: A transaction costs perspective. Entrepreneurship Theory \& Practice, 21(Spring): 23-39.

Siri Terjesen ( $\mathrm{PhD}$, Cranfield University) is an assistant professor in the Management and Entrepreneurship Department at the Kelley School of Business at Indiana University. Concurrently, she is a visiting research fellow at the Max Planck Institute of Economics in Jena, Germany. Her primary research interests are international entrepreneurship and strategic management. She has published in journals including Strategic Management Journal, Small Business Economics, Journal of Business Ethics, Entrepreneurship Theory \& Practice and Venture Capital and is co-author (with Anne Huff, Steve Floyd and Hugh Sherman) of Strategic Management.

Jolanda Hessels ( $\mathrm{PhD}$, Erasmus University Rotterdam) is an assistant professor at the Erasmus School of Economics and a researcher at EIM Business and Policy in Zoetermeer. Her research interests include internationalization of SMEs, international new ventures and cross-country comparisons of entrepreneurship. Her work has been published in several journals including Small Business Economics as well as book chapters. Jolanda is the project coordinator of the Global Entrepreneurship Monitor (GEM) for the Netherlands. 